\title{
El desplazamiento forzado: un desafío a la pastoral suburbana*
}

Consuelo Vélez, Ángela María Sierra, Carlos Julio Rozo cmf, Andrés Rodríguez oar, Alberto Camargo, Susana Becerra“

Para citar este artículo: Vélez, Consuelo; Sierra, Ángela María; Rozo cmf, Carlos Julio; Rodríguez oar, Andrés; Camargo, Alberto y Becerra, Susana. "El desplazamiento forzado: un desafío a la pastoral (sub)urbana". Franciscanum

161, Vol. LVI (2014): 221-261.

\section{Resumen}

En situaciones de violencia y conflicto armado como se viven en la realidad colombiana, el compromiso pastoral de las iglesias ha de dar una respuesta eficaz. Por eso la pastoral suburbana (de las periferias) que opta por el principio compasión-misericordia como horizonte de su acción, puede responder de manera más integral a esta realidad. Este artículo indagó sobre esta situación y pretende ofrecer algunas pistas de acción para una pastoral en las grandes urbes que tome en

\footnotetext{
Artículo resultado de la investigación «El desplazamiento forzado: un desafío para la pastoral urbana», financiada por la Pontificia Universidad Javeriana (ID Proy 4833) y por el Grupo científico «Iglesia Mundial» de la Conferencia Episcopal alemana. Este proyecto formó parte de un proyecto internacional e interdisciplinario coordinado por la Universidad de Osnabrück - Alemania desde enero de 2011 habiendo culminado con la realización del Congreso Internacional «Dios vive en la ciudad» que se llevó a cabo en el mes de febrero de 2013 en México D.F.

Olga Consuelo Vélez, Doctora en Teología, profesora titular de la Facultad de Teología en la Pontificia Universidad Javeriana, contacto: ocvelez@javeriana.edu.co. Ángela María Sierra, Magíster en Teología, profesora asistente de la Facultad de Teología de la Pontificia Universidad Javeriana, contacto: angela.sierra@javeriana.edu.co. Carlos Julio Rozo, cmf, Director del programa de Teología y Filosofía de la Universidad San Alfonso María de Ligorio, contacto: carlos.rozo85@ gmail.com. Andrés Rodríguez, oar, candidato a la Maestría en Teología en la Pontificia Universidad Javeriana, director de pastoral de la Universitaria Agustiniana, contacto: frgarohe@hotmail.com. Alberto Camargo, Experto en Pastoral Urbana, Presbítero de la Diócesis de Engativá, contacto: juglar3@yahoo.com. Susana Becerra, Magíster en Teología, profesora asistente de la Facultad de Teología de la Pontificia Universidad Javeriana, contacto: sbecerra@javeriana.edu.co.
} 
serio la realidad del desplazamiento y como el buen samaritano del evangelio se detenga en el camino para ayudar a levantar a tantos caídos en el camino, como consecuencia de este fenómeno.

\section{Palabras clave}

Pastoral suburbana, desplazamiento, compasión-misericordia, iglesia.

\section{The forced displacement: a challenge to suburban pastoral}

\section{Abstract}

In response to situations of violence and armed conflict as those present in the Colombian reality, the church's pastoral commitment should be effective. Then, the suburban pastoral (periphery pastoral), that promotes mercy and compassion as principles of its action, can respond to this reality more comprehensively. This article inquires about this situation and seeks to offer some clues in order to make pastoral action in the big cities, taking into account the reality of displacement. Hopefully, the urban pastoral will be like the Good Samaritan portrayed in the Gospel: it will stop along the way to help those who have fallen as a result of violence in Colombia.

\section{Keywords}

Suburban pastoral, displacement, mercy-compassion, church.

\section{Introducción}

Este artículo recoge los resultados de la investigación realizada sobre pastoral urbana y personas en situación de desplazamiento. 


\section{El trabajo de campo contó con la participación de quince personas} víctimas del desplazamiento forzado ${ }^{1}$, un grupo de agentes de pastoral $^{2}$ y un grupo de personas que pertenecen a organizaciones o instituciones que tienen proyectos de intervención frente a la realidad del desplazamiento ${ }^{3}$, con los cuales se indagó sobre la respuesta que las iglesias ${ }^{4}$ están dando a esta situación y de qué manera una pastoral urbana o suburbana ${ }^{5}$ debería proyectarse para que esta realidad, que afecta al país, no quede fuera de su acción. Para acercarse a esta reflexión se realizaron las técnicas de la entrevista a profundidad $^{6}$ desde el enfoque diferencial ${ }^{7}$, el grupo focal ${ }^{8}$ y un taller ${ }^{9}$ sobre la percepción que las personas entrevistadas, tienen de su propio cuerpo. Los datos se organizaron y sistematizaron a partir

16 varones y 9 mujeres. 2 afrodescendientes, 5 indígenas.

24 varones (3 párrocos y 1 pastor evangélico) y 2 mujeres (1 religiosa y 1 catequista).

35 organizaciones pertenecientes a comunidades religiosas masculinas y femeninas en las que trabajan laicos/as quienes, desde sus diferentes profesiones, brindan una atención integral.

4 Aunque nos centramos más en la iglesia católica, se contó con la participación de un pastor evangélico. Además las personas entrevistadas participan de varias iglesias. De ahí que nos refiramos a las iglesias en plural.

5 Con el término suburbana nos referimos a la pastoral de las periferias habitadas por personas que en cierto sentido mantienen el ambiente rural del que proceden pero que, al mismo tiempo, padecen las consecuencias de la gran ciudad que los excluye de sus servicios por su precaria condición socioeconómica.

6 Las entrevistas en profundidad implican hacer preguntas, escuchar y registrar las respuestas y posteriormente hacer otras preguntas que aclaren o amplíen un tema particular. Las preguntas son abiertas y los entrevistados deben expresar sus percepciones con sus propias palabras. Las entrevistas en profundidad tienen la finalidad de comprender la opinión que tienen los entrevistados acerca de un tema particular, su terminología y sus juicios Cf. Entrevista a profundidad, consultada en mayo 7, 2013, http://es.scribd.com/doc/6904791/Entrevista-de-Profundidad\#download.

7 El enfoque diferencial consiste en discriminar la población según su edad, sexo, etnia, lugar de procedencia, condición socioeconómica, composición familiar, pertenencia religiosa, grado de escolaridad y todos aquellos aspectos que puedan aportar un conocimiento adecuado de los sujetos a los que se quiere llegar con los resultados de la investigación.

8 Un grupo focal consiste en una entrevista grupal dirigida por un moderador a través de un guion de temas o de entrevista. Se busca la interacción entre los participantes como método para generar información. El grupo focal lo constituye un número limitado de personas: entre 4 y 10 participantes, un moderador y, si es posible, un observador. A través de él se consigue información en profundidad sobre lo que las personas opinan y hacen, explorando los por qué y los cómo de sus opiniones y acciones. Se trabaja con la información que se expresa en los discursos y conversaciones de los grupos. El lenguaje es el «dato» a analizar, comprender e interpretar. Cf. M. A. Prieto Rodríguez y J. C. March Cerdá, «Paso a paso en el diseño de un estudio mediante grupos focales», Aten Primaria 6, Vol. 29 (2002): 366-373, consultado en mayo 7, 2013, http://es.scribd.com/doc/74110812/Que-es-el-grupo-focal\#download.

9 El taller tuvo cuatro momentos a saber: (1) Encuentro con el propio cuerpo: autorreconocimiento y reconocimiento colectivo mediante las técnicas de la «danza consciente» y el «espejo»; (2) La capacidad del cuerpo de «narrar» (técnica de la silueta); (3) El cuerpo como signo de la realidad del desplazamiento (técnica de las imágenes y relatos de vida); (4) Celebrar la vida a través del cuerpo comunitario (celebración orante y festiva). 
de las categorías transversales a esta investigación: sujetos sufrientes, desplazamiento, cuerpo, género, principio compasión-misericordia, memoria y pastoral urbana ${ }^{10}$. Todo ello conduce a las conclusiones o pistas de acción, resultado de la investigación.

La primera parte de este artículo corresponde a la presentación de la metodología, los antecedentes y la justificación. La segunda presenta, de manera muy breve, una interpretación de los datos surgidos de las técnicas de recolección de información. En la tercera parte se presenta el marco teórico de la investigación. Finalmente, en la cuarta parte, se ofrecen las reflexiones que pueden contribuir a la realización de una pastoral suburbana que responda efectivamente a las necesidades, expectativas y, especialmente, a la dimensión espiritual de las personas en situación de desplazamiento.

\section{Precisiones metodológicas}

\subsection{El método}

Esta investigación se realizó con el aporte de las ciencias sociales mediante las técnicas antes anotadas, pero también con la mediación hermenéutica, propia de las ciencias humanas y, en concreto, de la teología. El método hermenéutico se entiende desde la ontología de la comprensión ${ }^{11}$, para la cual no existe una interpretación neutra sino una interpretación situada que es apropiada por un intérprete también situado, haciendo del acto de comprender una relación de ida y vuelta entre el sujeto que interpreta y la realidad a ser interpretada. Desde este presupuesto ontológico, la teoría hermenéutica se entiende como un círculo en el cual interactúan recíprocamente el texto, el contexto y el pretexto. Para nuestra investigación el contexto

10 El tratamiento de cada una de estas categorías se encuentra disponible en formato digital.

11 «La ontología de la comprensión no es un método, pero es el presupuesto a partir del cual se propone la circularidad hermenéutica del texto-contexto-pretexto. Según Alberto Parra, los pasos antes señalados corresponden a los tres campos metodológicos señalados por la teología de la liberación, a saber: la praxis de liberación como acto primero, la reflexión crítica como acto segundo, a la luz de la fe, como acto tercero». Alberto Parra, Textos, contextos, pretextos (Bogotá: Pontificia Universidad Javeriana, 2003), 312-313. 
es la realidad de los sujetos sufrientes situados en Ciudad Bolívar. El pretexto o intencionalidad es la pregunta por la potencialidad que tiene el evangelio para ofrecer una palabra dignificadora y liberadora que llegue eficazmente a sus destinatarios respondiendo a sus situaciones existenciales. El texto son los datos de la revelación y la fe y las reflexiones sistemáticas que enmarcan esta investigación, expuestas en el marco teórico.

\subsection{Antecedentes}

La Arquidiócesis de Bogotá se preguntó al iniciar su vi Sínodo ${ }^{12}$ : «desde dentro y desde fuera ¿̇cuál es el papel real que la Iglesia está desempeñando en medio de la ciudad? ¿Quiénes son sus interlocutores?» La respuesta a estas preguntas reconoce que si bien se ha mantenido un interés por la pastoral de la ciudad, sí hay «un desfase» ${ }^{13}$, o un desbordamiento en sus acciones. De alguna manera esto lo expresó el mismo cardenal en la inauguración del Sínodo: «En este mundo que evoluciona tan rápidamente corremos el riesgo de perder el contacto con la realidad circundante y por tanto de marchar en un camino paralelo pero no convergente con el de los hombres de hoy, a quienes la Iglesia debe llevar el mensaje de salvación» ${ }^{14}$.

Lo anterior es clave para ubicar el tema de la pastoral suburbana en la localidad de Ciudad Bolívar, la cual corresponde a la zona pastoral del Espíritu Santo, ya que este territorio de la ciudad, en límites con el municipio de Soacha, se ha venido poblando de manera desordenada, especialmente a partir de los años 50 como fruto de la violencia que vivió el país y que obligó a miles de colombianos a

12 El vi Sínodo fue convocado por el cardenal Mario Revollo y se realizó entre los años 1989-1998, fruto del cual nació el Plan Arquidiocesano de pastoral urbana, que se llamó «Por una Ciudad Samaritana». Declaraciones sinodales 1998. Plan Global de Pastoral. Arquidiócesis de Bogotá. 1999-2008 (Bogotá: Publicaciones de la Arquidiócesis de Bogotá, 1998).

13 R. Caramuru, «Informe general», en R. Caramuru et ál., La Iglesia al servicio de la ciudad (Barcelona: Nova Terra-Dilapsa, 1967), 191-193. Citado por Jaime Mancera, «De una pastoral en la ciudad a una pastoral urbana», Revista Seminario Bogotense 1 (2002), consultada en junio 14, 2013, http:// pastoralurbanabogota.blogspot.com/2009/01/revista-seminarium-bogotense-n-1-2002.html.

14 Revollo, Mario. Palabras pronunciadas en el contexto de la inauguración del VI Sínodo, cf. Declaraciones sinodales 1998. Plan Global de Pastoral. Arquidiócesis de Bogotá. 1999-2008, op. cit., N. ${ }^{o} 3$. 
migrar hacia las grandes ciudades. Estas personas se fueron ubicando en las periferias de la ciudad, donde los servicios básicos siempre han sido escasos y la pobreza creciente, generando así grandes cinturones de miseria. Hoy, 60 años después, cuando las confrontaciones no han terminado en el país y el conflicto armado se agudiza ${ }^{15}$, la llegada de personas y familias víctimas del desplazamiento forzado se ha recrudecido, convirtiéndose en un fenómeno complejo y socialmente inmanejable.

Como fruto del Plan Colombia ${ }^{16}$, el rompimiento de los diálogos del Caguán ${ }^{17}$ y la llegada de la Seguridad Democrática (1998-2008) $)^{18}$ los desplazamientos forzados de personas y familias se incrementaron ostensiblemente en las zonas de frontera ${ }^{19}$, de ciudades como Bogotá. Lo grave es que estos nuevos interlocutores de la ciudad, quienes en su mayoría se identifican como católicos, sobreviven en condiciones de «crítica pobreza $»^{20}$.

Siguiendo a la Consultoría para los Derechos Humanos y el desplazamiento forzado (CODHEs), se puede afirmar que Bogotá es la ciudad que recibe el mayor número de personas en situación de desplazamiento. En el año 2010, el número de desplazados en Bogotá

15 Según el «Proyecto Víctimas» liderado por la Revista Semana, entregan un registro de 5.5 millones de víctimas en Colombia. Cf. Revista Semana, proyecto Víctimas, consultado en junio 14, 2013, www.semana.com/Especiales/proyectovictimas/crimenes-de-la-guerra/masacres-desplazamiento/ index.html.

16 El Plan Colombia o Plan para la paz, la prosperidad y el fortalecimiento del Estado es un acuerdo bilateral entre los gobiernos de Colombia y Estados Unidos. Se firmó en 1999 bajo el gobierno de Andrés Pastrana y Bill Clinton con el objetivo de generar una revitalización social y económica, terminar el conflicto armado en Colombia y crear una estrategia antinarcóticos. Este plan se ha mantenido en las administraciones de Álvaro Uribe Vélez y Juan Manuel Santos. Los objetivos no se han conseguido y, por el contrario, han generado más violencia y un espíritu de guerra en algunos sectores.

17 Se refiere al intento de firmar la paz con la Farc durante los años 1998-2002. Para esto se acordó despejar una zona llamada «San Vicente del Caguán» en la que la guerrilla pudo permanecer sin ser perseguida por el gobierno nacional. Ante el fracaso de los diálogos, el presidente Pastrana decide romper ese proceso provocándose así, un recrudecimiento del conflicto interno colombiano.

18 Fue la política gubernamental del expresidente Álvaro Uribe Vélez, política altamente guerrerista que ha mostrado su fracaso en el recrudecimiento de la guerra, los falsos positivos, el alto presupuesto nacional destinado a las fuerzas armadas, entre otros aspectos.

19 Nos referimos a los barrios que colindan con otros municipios y/o departamentos, como es el caso de Ciudad Bolívar, la localidad N. ${ }^{\circ} 19$ del Distrito Capital, lugar a donde llega el mayor número de personas y familias en situación de desplazamiento.

20 Boletín Informativo codHes 75 (2009), consultada en septiembre 25, 2012, www.codhes.org. 
alcanzó la cifra de 57000 personas, ubicándose mayoritariamente en el municipio de Soacha y en la localidad de Ciudad Bolívar ${ }^{21}$. En 2012 un mapa del Consejo Noruego para los Refugiados puso a Colombia, en números absolutos, como el primer país del mundo en desplazamiento interno ${ }^{22}$.

En términos generales el desplazamiento significa un costo social y cultural muy fuerte para las personas que llegan a la ciudad de manera abrupta, porque al obligarlos a emprender rumbos distintos de manera individual y fragmentada, también se rompen relaciones y se destruyen sistemas de producción agrícola, y de producción social y cultural. Los desplazados solos o en familia ingresan silenciosamente a la ciudad, pasan así de zonas rurales a hacinamientos urbanos. Provenientes de comunidades generalmente caracterizadas por relaciones tradicionales, se enfrentan a los determinantes de una ciudad moderna en donde el mapa de lo sacralizado se ha modificado ${ }^{23}$ y sus proyectos de vida se difuminan en medio de la pauperización, la inseguridad y las condiciones deshumanizantes que les ofrece el barrio a donde llegan.

La Iglesia como institución se convierte, en Ciudad Bolívar, en un punto de referencia de las personas y familias que llegan diariamente a esta localidad. Según datos aportados por el programa «Vidas Móviles» ${ }^{24}$, el 70\% de las familias desplazadas, al momento de llegar a la ciudad, tienen a la Iglesia católica como el referente más importante y a donde acuden, en primer lugar, para buscar orientación y ayuda ${ }^{25}$.

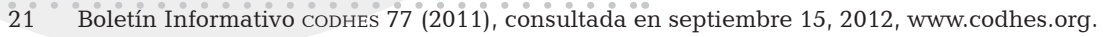

22 Cf. Revista Semana, proyecto Víctimas, op. cit.

23 Cf. Martha Bello, Las familias desplazadas por la violencia. Un tránsito abrupto del campo a la ciudad. Ponencia presentada al Congreso Internacional Cultura, Familia y Sociedad (Bogotá: Universidad Nacional de Colombia, mayo de 1998), 6.

24 Es el programa de la Universidad Javeriana que a través de varias de sus facultades, acompaña, orienta y atiende a familias en situación de desplazamiento forzado en la localidad de Ciudad Bolívar.

25 Cf. Amelia Fernández y Diego Felipe Gutiérrez, «Proyecto Vidas Móviles: caracterización de las poblaciones en situación de desplazamiento y vulnerable receptora en la localidad de Ciudad Bolívar, Bogotá, Facultad de Medicina, Pontificia Universidad Javeriana», Revista Universitas Médica 1, Vol. 50 (2009): 41-57. Consultada en mayo 25, 2013. www.redalyc.org/articulo.oa? $i d=231018725004$ 
De acuerdo a una indagación virtual ${ }^{26}$ sobre la Zona Pastoral Episcopal del Espíritu Santo a la que pertenece la localidad de Ciudad Bolívar, se conoció que esta tiene una serie de servicios (Pastoral Social, Banco de Alimentos, Programa de Movilidad Humana, etc.) que ofrece a las comunidades más vulnerables. Sin embargo, en el escenario geográfico en el cual se ubica esta investigación, la población se queja de un abandono y desconocimiento de sus necesidades por parte de la Iglesia y dicen no sentirse acompañados por ella. Las personas en situación de desplazamiento, esperarían que la Iglesia los acompañe de manera más decidida e integral en los procesos de re-comenzar su vida en la ciudad. De acuerdo con los testimonios recogidos de víctimas del desplazamiento forzado, parece que la Iglesia tiende a definir su orientación pastoral, en consonancia con un modelo pastoral ${ }^{27}$, que desde sus opciones y comprensiones, no siempre se corresponden con las problemáticas y expectativas de estos sujetos sufrientes ${ }^{28}$. Nuestra propuesta es que la pastoral suburbana enfocada desde «el principio compasión misericordia» puede brindar pistas de acción transformadoras de esa realidad.

\subsection{Justificación}

El Plan Global de Pastoral de la Arquidiócesis de Bogotá, 1999-2008, nació como fruto del Sínodo de Bogotá, y se propuso trazar un programa de pastoral urbana centrado en ser la «Iglesia de la misericordia al servicio en la ciudad ${ }^{29}$, llamada a ser buena noticia del Reino desde la conformación de pequeñas comunidades, haciéndose prójimo de los varones y mujeres «sufrientes en la

26 Vícaría Episcopal Territorial del Espíritu Santo, consultada en septiembre 19, 2011, www. arquibogota.org.co/?idcategoria $=336$.

27 La V Conferencia del Episcopado Latinoamericano y del Caribe, afirmó que llegó el momento de pasar de una pastoral de mera conservación a una pastoral decididamente misionera (DA 370) o en términos de Casiano Floristán de una pastoral de cristiandad a una pastoral misionera. Cf. Casiano Floristán, Teología práctica, teoría y práctica de la acción pastoral (Salamanca: Sígueme, 2002), 236-241. Con la categoría «sujetos sufrientes» queremos expresar la realidad de las personas en situación de desplazamiento.

29 Cf. Declaraciones sinodales 1998. Plan Global de Pastoral. Arquidiócesis de Bogotá. 1999-2008, op. cit., N. ${ }^{\circ} 53$. 
ciudad $»^{30}$. No se conoce evaluación de dicho plan y actualmente la Arquidiócesis lanzó un nuevo plan «La Iglesia en la ciudad» (20132022) que aunque retoma algunas de las inspiraciones fundamentales del antiguo plan, no pone en el centro de su acción la samaritanidad ni la situación de los desplazados.

Por otra parte, la pastoral suburbana implica grandes desafíos, pero tal como lo afirma Bernardino Sândalo:

La Iglesia se pone en movimiento en su pastoral agraria con gusto, pero tiene serias dificultades para evangelizar la ciudad y queda aturdida delante de la Metrópoli. Nuestras propuestas pastorales contemplan, en gran parte, la ciudad pequeña, la zona rural; jamás la metrópoli, el hombre en la era moderna (límites jurídicos de las parroquias, diócesis, días de precepto, liturgia...). Frecuentemente, aplicamos soluciones del siglo IV o vi para la problemática del siglo xx (...). De manera especial, la Iglesia necesita despojarse de cosas que fueron óptimas en el pasado y que dieron respuestas al hombre rural, para comprometerse con el Hombre-Urbano, con la ciudad, aceptando el desafío de lo nuevo con nuevas y aún no experimentadas formas pastorales ${ }^{31}$.

Por su parte, Aparecida reconoce que en la Iglesia «se notan actitudes de miedo a la pastoral urbana, tendencias a encerrarse en los métodos antiguos y de tomar una actitud de defensa ante la nueva cultura, de sentimientos de impotencia ante las grandes dificultades de las ciudades" ${ }^{32}$. Llega incluso a afirmar que la Iglesia necesita de «una fuerte conmoción que le impida instalarse en la comodidad, el estancamiento y en la tibieza al margen del sufrimiento de los pobres del Continente» ${ }^{33}$.

En ciudades como Bogotá, en razón de la modernización y desarrollo de la urbe, con frecuencia se excluye a los más pobres y, con más razón, a las personas en situación de desplazamiento, como lo afirma Alejandro Castillejo:

\footnotetext{
30 Cf. Ibíd., N. ${ }^{\circ} 57$.

31 Cf. Bernardino Sândalo, "Cultura urbana e evangelização», Revista Eclesiástica Brasileña 196 (1989): 878.881.

32 Celam, V Conferencia General del Episcopado Latinoamericano Aparecida, N. ${ }^{\circ}$ 513, consultada en septiembre 19, 2011, www.celam.org/conferencia_aparecida.php.

Ibíd., N. ${ }^{\circ} 362$.
} 
Desde formas aparentemente sutiles que oscilan entre el aislamiento y la separación, la persona en situación de desplazamiento es confinada al lugar simbólico de la lenta degradación de su humanidad. Como los estigmatizados llevan tatuado sobre su piel los signos indelebles de su diferencia, diferencia que no es más que una invención de la ciudad que habitamos ${ }^{34}$.

La persona desplazada, al ser abruptamente violentada a dejar su tierra y todo lo que le era conocido, se enfrenta a una realidad compleja en la ciudad que desestructura las diferentes redes de intercambio que configuraban su vida antes del desplazamiento. La relación entre la persona que se desplaza y el nuevo territorio que ahora ocupa, se transforma totalmente. En otras palabras, la afección que acontece en esas personas se manifiesta en todas las dimensiones de su ser personal, por lo cual requiere una atención integral.

Ante esta abrumadora realidad, la Iglesia no puede dar un rodeo y seguir de largo, como si no pasara nada. Por lo tanto, esta investigación se justifica en razón de los aportes bíblico-teológicos que se pueden ofrecer a la pastoral suburbana para que la Iglesia responda mejor a los desafíos que presentan las subjetividades sufrientes -estos nuevos rostros que duelen ${ }^{35}$ - desde el principio compasión-misericordia, aspirando a dejar de ser una Iglesia que camina «paralela a la ciudad» a una «Iglesia samaritana» que se detiene frente a los caídos en el camino y responde a sus necesidades y sufrimientos.

\section{El desplazamiento forzado: realidad dolorosa e interpelación inaplazable}

Los datos recogidos ${ }^{36}$ desbordan cualquier intento de sistematización, porque son historias de vida que no se pueden sistematizar con palabras. Todas ellas describen la situación difícil o límite que atraviesan, en su condición de desplazamiento, porque carecen de

Alejandro Castillejo, Poética de lo otro. Para una antropología de la guerra, la soledad y el exilio interno en Colombia (Bogotá: ICANH y Colciencias, 2000), 135.

35 Cf. Celam, V Conferencia General del Episcopado Latinoamericano Aparecida, op. cit., N. ${ }^{\circ} 402$.

36 Estos datos se encuentran en formato digital. No se anexan al artículo por razones de espacio. 
lo básico y tienen que comenzar de nuevo, a partir prácticamente de «nada». La mayoría de personas contaban con condiciones de vida dignas antes del desplazamiento aunque su nivel educativo, en general, era bajo. Pero el desplazamiento no solo las sacó de un territorio geográfico sino del «territorio existencial» de lo que había conformado su vida antes del desplazamiento: parientes, amigos, tradiciones culturales y religiosas.

El desplazamiento produce la desubjetivación o ambigüedad de los sujetos. En algunos contextos es mejor no decir que se es desplazado para no ser estigmatizados, en otros, conviene decirlo, para recibir ayudas. Desde la perspectiva de género se percibe que es diferente el desplazamiento para varones y mujeres. A cada uno les afecta de manera diferente y es necesario tener esto en cuenta.

Interesa destacar la experiencia de Dios y de Iglesia que tienen los desplazados. La mayoría provienen de un catolicismo con una religiosidad popular (90\%). Pero la experiencia vivida hace que muchos de ellos tengan preguntas religiosas de fondo: ipor qué Dios permite que les pasen tantas desgracias? Esto lleva a que unos se alejen de Dios y otros, por el contrario, permanezcan con fe y hasta se aferren más a Dios para salir de esa situación. Las mujeres permanecen más en su fe. No así los jóvenes que al llegar a la ciudad pierden mucho más su relación con Dios. Algunas personas han cambiado de Iglesia porque encuentran más apoyo en otras confesiones cristianas. Algunas permanecen en distintas iglesias, sin tener mucho problema de alternar según sea el día o la actividad en la que participen.

El trabajo de las Iglesias frente a la realidad del desplazamiento se ubica en la pastoral social, ayudándoles a cubrir sus necesidades básicas pero sin ofrecer, la mayoría de las veces, una ayuda integral. Aunque existen esfuerzos por una pastoral liberadora, se percibe temor a asumir esta realidad y ese temor se refuerza con la ambigua posición eclesial de no querer meterse en asuntos sociales, por temor a traicionar su misión religiosa. Esta posición es ambigua porque por el misterio de la encarnación, Dios se revela en toda la historia y nada 
queda fuera de su acción. Falta mucha articulación entre las mismas iglesias y entre estas y las ong. Por lo anterior, muchas personas en situación de desplazamiento mantienen una actitud crítica frente a unos y otros y desearían, de parte de la Iglesia, un mayor testimonio y una mayor mediación con el conflicto armado que causa millones de víctimas en el país.

Otro aspecto importante es la relación desplazamiento-cuerpo. El cuerpo es también un «territorio» donde quedan las marcas de esta dramática situación que expresan las heridas y dolores de una historia que unas veces se rechaza y otras se oculta. Hablar de cuerpo es hablar de la vida y remitirse a las huellas y cicatrices permite evidenciar emociones, identificar duelos no resueltos y experiencias para trabajar existencial y espiritualmente. Los cuerpos de las personas son textos abiertos que permiten reconocer otras realidades profundas de lo que vive y siente un/a desplazado/a en la gran urbe.

\section{Hacia la construcción de una pastoral de la misericordia capaz de levantar a los caídos en el camino}

El encuentro con la realidad de las personas en situación de desplazamiento nos invita a trazar algunas líneas para una pastoral suburbana. Aquí nos proponemos señalar un marco teórico que nos permita, en la parte final de este artículo, formular unas pistas de acción. Iniciamos retomando el contexto o realidad de los sujetos sufrientes que son la preocupación fundamental de nuestra reflexión, posteriormente desarrollaremos el principio compasión misericordia y otras reflexiones teológicas que de él se derivan, como horizontes que dan sentido a una pastoral de la misericordia en la ciudad.

\subsection{Contextualidad urbana y sujetos sufrientes}

El crecimiento de la ciudad de Bogotá se circunscribe dentro del gran marco de comprensión propio de las megalópolis latinoamericanas. El fenómeno es de proporciones incontenibles, generando problemáticas 
ambientales, sociales y urbanas. No son menos notables otros factores que contribuyen significativamente a la consolidación de este fenómeno, tales como el desplazamiento forzado, las migraciones y la debilidad en seguridad y economía de las zonas rurales ${ }^{37}$.

Para nuestro interés, no podemos perder de vista este desafiante problema con su carga histórica, política y cultural. Las implicaciones físico-espaciales y sociales del fenómeno, son un factor históricopolítico que juega decisivamente en el conocimiento e interpretación teológica que nos es menester hacer de las zonas suburbanas, escenarios de asentamiento de la población desplazada.

La expansión urbana, como fenómeno multimodal, coloca en el epicentro de su fuerza exógena, como primer objetivo de afectación, la condición de vulnerabilidad de los sujetos urbanos. Esta dinámica sociogeográfica propia de las megaurbes, en el caso de Bogotá, está intervenida por el desplazamiento forzoso, ubicado como el primero en el mundo, según la tabla comparativa de los conflictos internos de un país ${ }^{38}$. Es preciso aclarar que, si bien en Colombia la principal causa de desplazamiento forzado es el conflicto armado, no es la única. Otros factores agravan el problema, como las Bacrim, los proyectos de desarrollo económico, la minería y los desastres naturales, entre otros. Estas condiciones colocan en el ojo del huracán a las personas en situación de desplazamiento, invisibilizando el sufrimiento que les acarrea este drama, cuyo grito se pierde en la complejidad que el caos urbano adiciona a su búsqueda de auxilio.

De cara a la invisibilidad de los sujetos sufrientes desplazados, se impone la generación de territorialidades emergentes, capaces de contrarrestar la pérdida de lo humano, dadoras de respuestas a las

37 Cf. Jair Preciado Beltrán, Bogotá región: crecimiento urbano en la consolidación del territorio metropolitano (Bogotá: Universidad Distrital Francisco José de Caldas, 2005), consultada en junio 20 , 2013, http://200.69.103.48/comunidad/dependencias/facultades/medioambiente/Documentos/Eventos/Seminario-Internacional/Ponencias-Centrales/BOGOTA\%20REGION\%20CRECIMIENTO\%20 URBANO.pdf.

38 Cf. Informe de la Agencia de la ONU para los refugiados, consultada en junio 20, 2013, www.acnur. org/t3/operaciones/situacion-colombia/desplazamiento-interno-en-colombia/. 
múltiples necesidades surgidas a causa de este embate. En este sentido, «la territorialidad es un organismo vivo que indica lo actuante, lo aprendiente; es una fuente compleja de vitalidad y un espacio de vida, es la capacidad que tenemos de concebir las relaciones con el espacio público, que muestra los procesos de construcción regidos desde una perspectiva ética, la convivencia con todo lo actuante. Por ello, cambiar los ambientes de no sentido, de consumismo, para dar paso a la reterritorialización, en donde emerge la relación del nuevo ambiente y un nuevo tipo de relaciones, es el reto que tenemos ahora» ${ }^{39}$. Este es uno de los vehículos que nos proporcionan los estudios urbanos y sociales, para crear territorios alternativos, nichos de vida en los que sea posible acoger a los desheredados de la tierra.

Los sujetos sufrientes, en esta investigación, son entendidos como sujetos liminales porque viven al límite y en las márgenes de la gran ciudad. Ellos no son reconocidos como miembros de un grupo o comunidad. Con frecuencia son identificados como intrusos y peligrosos que amenazan la seguridad de la zona. Su naturaleza radica en la ambigüedad, en la movilidad de su representación y definición, por lo cual Alejandro Castillejo afirma que alrededor de los sujetos desplazados giran en Colombia metáforas e imágenes que los asocian a lo liminal porque «el desplazado es, en muchos sentidos, forzado -es decir, carente de la mediación de un dispositivo ritual y simbólico- a convertirse en un sujeto fronterizo» ${ }^{40}$.

\subsection{Visión teológica de este fenómeno urbano}

La comprensión dominante del territorio es el gran escollo a superar. Las personas en desplazamiento dejan su tierra y en el contexto urbano son sometidas a la lenta degradación. Sus vínculos territoriales quedan desconfigurados, son víctimas de la indiferencia y de la estigmatización, condiciones del nuevo «territorio» que

39 Oscar Useche, ponencia «Territorio, nuevas formas de desarrollo. El territorio como organismo vivo», Cuarto Congreso de Pastoral Urbana. Diócesis de Engativá, 2012.

40 Alejandro Castillejo, op. cit., 79. 
ahora les enfrenta. El crecimiento desmesurado de la urbe pasa por encima de este drama humanitario. Por eso la ciudad constituye un gran desafío para la reflexión teológica de la Iglesia. Desde este eje, nuestra acción pastoral mira la ciudad. Nos interesa, en consecuencia, encontrar el lugar teológico de esta acción ${ }^{41}$. Ante esta situación de sufrimiento de los desplazados, la Iglesia no puede pasar de largo. Su misión evangelizadora consiste en interpretar los signos de Dios frente a esta realidad, su escucha y comunión con este sufrimiento, su toma de postura ante él, la expresión sentida de su compasión-misericordia.

Una teología de la ciudad, consecuentemente, fija su mirada en este hecho concreto, sin perder la referencia del gran contexto urbano, leyendo la situación de sufrimiento en este gran marco, construyendo la inteligencia del fenómeno urbano, para generar respuestas adecuadas y compromisos eficaces.

Este ejercicio del pensamiento y del quehacer teológico, nos ofrece herramientas para abordar el fenómeno urbano como un hecho cultural, como la «cultura adveniente», de la que ya Puebla hablaba como un claro desafío para la Iglesia. Esto genera una «pastoral urbanamente inculturada» o una inculturación del evangelio en la ciudad, en la vida de sus habitantes urbanos. De no ser así, sería una fe que no «crea cultura», o que no «fue suficientemente anunciada, o no fue objetivamente asimilada, o no fue plenamente vivida» ${ }^{42}$.

Esta acción pastoral inculturada constata, por la integralidad de su quehacer, que Dios está presente en la ciudad, que «Dios habita la ciudad $»^{43}$ y nos da las señales de su proyecto de vida plena y abundante en ella. Interpretar estos signos en la complejidad urbana

41 Para una teología de la ciudad Cf. Carlos María Galli, Dios vive en la ciudad. Hacia una nueva pastoral urbana a la luz de Aparecida (Buenos Aires: Ágape Libros, 2012), 123-206.

42 Francisco Niño, «De la pastoral en la ciudad a la pastoral urbana», Cuestiones Teológicas 88, Vol. 37 (2010): 407.

43 Con esta expresión se convocó el Primer Congreso Internacional de Pastoral Urbana, «Dios habita la ciudad», realizado en Ciudad de México del 6 al 9 de agosto de 2007. Organizaron las universidades J. Gutemberg de Alemania, Intercontinental, Iberoamericana y Pontificia de México. 
es nuestra tarea teológica ${ }^{44}$. Ella ha de «desentrañar el mensaje cristiano sobre la ciudad, asumir el problema de la pastoral urbana, iluminar las tareas que se imponen los creyentes en la ciudad y estudiar las consecuencias de una vida metropolitana moderna, que suscita una nueva modalidad de vida cristiana ${ }^{45}$.

Estos principios básicos de una teología urbana estarían incompletos si su encarnación en la culturalidad de la ciudad no tiene como centro la vida de los que sufren. Este presupuesto rige nuestra entrada en el quehacer teológico urbano, que acompaña una opción real por los sujetos sufrientes desplazados en la marginalidad suburbana de Ciudad Bolívar. Este interés nos lleva a preguntarnos ¿̇uál es el paso de Dios por la vida de estas personas en situación de desplazamiento? ¿Qué signos nos está dando para que no pasemos de largo y escuchemos la profundidad de su grito?

Este enfoque sobre los sujetos sufrientes determina nuestra opción teológica urbana. Al respecto, el Magisterio de la Iglesia Latinoamericana tiene una profunda mirada. El preámbulo nos lo dio la Constitución Gaudium et Spes: «El gozo y la esperanza, la angustia y la tristeza de los hombres de nuestros días, sobre todo de los pobres y toda clase de afligidos, son también gozo y esperanza, tristeza y angustia de los discípulos de Cristo, y nada hay verdaderamente humano que no tenga resonancia en su corazón» ${ }^{46}$.

Asimismo, la interpretación de este pensamiento lo hizo la Conferencia de Medellín, cuando propuso la opción preferencial por los pobres como sujetos sufrientes. Fue un hecho «interpretativo y vivencial ${ }^{47}$. Puebla ratificó para el subcontinente esta opción, desde la

44 La exposición de Aparecida en este sentido, abre una brecha para la reflexión de la teología pastoral urbana puesta a tono con los grandes cambios culturales, sociales y religiosos de nuestras ciudades. Cf. Celam, V Conferencia General del Episcopado Latinoamericano Aparecida, op. cit., N. ${ }^{0}$ 509-119. Francisco Niño, La Iglesia en la ciudad. El fenómeno de las grandes ciudades en América Latina, como problema teológico y desafío pastoral (Roma: Tesis Gregoriana, 1996), 197-198.

46 Gaudium et Spes, N. ${ }^{\circ} 1$.

47 Jon Sobrino, «Con Medellín Dios pasó por América Latina, ¿̇con quién pasa ahora? Reflexión para la cuaresma 2012», Informativo Eclesalia.net 23.02.12, consultada en abril 1, 2013, http://eclesalia. wordpress.com/2012/02/23/con-medellin-dios-paso-por-america-latina-con-quien-pasa-ahora/. 
que cuestionó la pobreza generalizada y extrema de nuestros pueblos ${ }^{48}$. En el mismo sentido, la afirmación de Santo Domingo es contundente, el rostro sufriente de Cristo está en los rostros sufrientes de los pobres, en clara alusión a la identidad de Jesús con los que sufren, en Mt 25, 31-46 ${ }^{49}$. Aparecida confirma la importancia de esta opción teológica: «Nuestra fe proclama que -Jesucristo es el rostro humano de Dios y el rostro divino del hombre-. Por eso la -opción preferencial por los pobres está implícita en la fe cristológica en aquel Dios que se ha hecho pobre por nosotros para enriquecernos con su pobreza-» ${ }^{50}$.

La contextualización de nuestro quehacer teológico urbano nos compromete con la visibilización de las personas en situación de desplazamiento, como sujetos sufrientes. Nos adentramos en la búsqueda de su espacio, conscientes de que no todos tendrán la oportunidad de regresar a su lugar de origen, pero todos con necesidad de darle sentido y significado al espacio que hoy habitan, fuente de una nueva relacionalidad forjada, quizás en contravía de la misma ciudad.

\subsection{Principio compasión-misericordia: opción por los que sufren}

Encontramos en el abordaje de $\mathrm{Metz}^{51}$, tres categorías de interpretación, desde las cuales hacemos la intelección del sufrimiento de las personas en situación de desplazamiento: memoria de las víctimas, compasión ante el sufrimiento y autoridad de los que sufren.

Estos tres componentes son el centro del Principio CompasiónMisericordia con el que buscamos dar una respuesta bíblicoteológica-práxica, que contribuya a reconstruir la condición humana de los que han sido victimizados, nuestros sujetos sufrientes.

48 Celam, ill Conferencia General del Episcopado Latinoamericano Puebla, N. ${ }^{\circ}$ 31, consultada en septiembre 19, 2011, www.celam.org/conferencia_puebla.php.

49 Celam, IV Conferencia General del Episcopado Latinoamericano Santo Domingo, N. ${ }^{\circ}$ 178, consultada en septiembre 19, 2011, www.celam.org/conferencia_domingo.php.

50 Discurso Inaugural, Cf. Celam, V Conferencia General del Episcopado Latinoamericano Aparecida, op. cit., N. ${ }^{\circ}$ 3; Cf. Ibíd., N. ${ }^{\circ} 392$.

51 Johann B. Metz «Compasión. Sobre un programa universal del cristianismo en la era del pluralismo cultural y religioso», en José A. Zamora (coord.), Foro «Ignacio Ellacuría». Solidaridad y cristianismo. Radicalizar la democracia (Estella: Verbo Divino, 2001), 263-276. 
La memoria es la condición de imposibilidad del olvido del sufrimiento de las víctimas. Es la «memoria passionis» de la tradición bíblica. El Dios bíblico mantiene esta memoria, las víctimas no olvidadas se convierten en criterio decisivo para la salvación que él otorga.

$\mathrm{Su}$ autoridad, como sujetos sufrientes, radica en que son sujetos de identidad, son el rostro mismo de Cristo sufriente en ellos y ellas. La pregunta por la atención al dolor de los sufrientes determina la salvación de los seres humanos (Mt 25, 31-46).

La compasión es la respuesta inmediata al sufrimiento de las víctimas, como lo expresa la parábola del buen samaritano (Lc 10, 25-37) ${ }^{52}$. Es la sensibilidad ante el sufrimiento de los demás ${ }^{53}$, según el estilo de vida de Jesús. Ese actuar muestra la unidad profunda entre el amor a Dios y el amor al prójimo. El interés propio cede ante la desgracia de los demás. El buen samaritano lo entrega como «una indeleble huella narrativa dejada por Jesús en la memoria de la Humanidad», es la irrupción de la «pasión por Dios, como compasión, como mística política de la compassio» ${ }^{54}$.

La compasión va unida a la memoria porque solo quien mantiene el recuerdo de los que sufren se empeña en trabajar porque la historia no se repita, sino que se supere. Al mismo tiempo, exige la lógica de la asimetría, donde la preocupación por las/los otros/as supera la relación simétrica que nos sitúa en lo inmediato y, en términos económicos, en la lógica del mercado. La asimetría responde a una articulación entre política y moral, donde la pregunta por la suerte del otro, ocupa un lugar central.

Para Jon Sobrino, la mirada sobre la condición de sufrimiento de los pobres sobrepasa notablemente la simple construcción teórica a que estamos acostumbrados. La acción pensante va mucho más

52 Para una exégesis de la parábola cf. Joseph Fitzmyer, El evangelio según Lucas, III, traducción y comentario 8,22-18,14 (Madrid: Ediciones Cristiandad, 1978), 276-291.

53 Afirmación contundente de Metz, que lo lleva a decir que esta sensibilidad ante los sujetos sufrientes es la única que podría posibilitar un diálogo mundial e interreligioso por la paz. Cf. Memoria passionis. Una evocación provocadora en una sociedad pluralista (Santander: Sal Terrae, 2007), 165. Ídem. 
hondo. «Si la razón no se torna -también- en razón compasiva y si la teología no se torna -también-en intellectus misericordiae, mucho me temo que dejaremos a los pueblos crucificados abandonados a su desgracia, con muchas razones y con muchas teologías» ${ }^{55}$. Aquí, según Sobrino, es como si la fe desapareciera cuando los que sufren son masacrados, violentados, desplazados. Si no hay una respuesta ante este sufrimiento, que equivale a estar frente al «Dios crucificado», tenemos una fe idolátrica. Cada vez que la fe no se mueve a responder al sufrimiento de los últimos, es idolátrica: $\mathrm{He}$ aprendido, pues, que "para decir toda la verdad siempre hay que decir dos cosas: en qué Dios se cree y en qué ídolo no se cree. Sin esa formulación dialéctica la fe permanece muy abstracta, puede ser vacía $y$, lo que es peor, puede ser muy peligrosa, pues permite que coexistan creencia e idolatría ${ }^{56}$.

La parábola del buen samaritano explicita la forma concreta de ejercer la misericordia. No es una referencia a las «obras de misericordia», sino a la estructura fundamental de la reacción ante las víctimas de este mundo. La interiorización del sufrimiento ajeno genera una re-acción ante el hecho del herido en el camino. Más que cumplir un mandamiento, la parábola muestra al samaritano fundamentalmente movido a misericordia. En este sentido, la misericordia tiene la condición de ser «Principio configurador» de todo el actuar humano ante el sufrimiento, al comienzo, durante y después de todo el proceso de la acción.

No es la misericordia, por tanto, un «sentimiento de compasión» sin praxis y sin análisis de las causas del sufrimiento, lo que podría llevar al alivio de necesidades particulares, a paternalismos y al abandono de la transformación de estructuras. Por eso Jon Sobrino habla no solamente de misericordia, sino de «Principio Misericordia»,

55 Jon Sobrino, El principio misericordia. Bajar de la cruz a los pueblos crucificados (Santander: Sal Terrae, 1992), 8. Seguimos fundamentalmente sus aportes en el resto del desarrollo de este tema. 
como Ernst Bloch no hablaba simplemente de esperanza, sino de «Principio Esperanza» ${ }^{57}$.

Por consiguiente, este principio es el amor específico que está en el origen de un proceso, pero que además permanece presente y activo a lo largo de él, le otorga una determinada dirección y configura los diversos elementos dentro del proceso. Ese-Principio Misericordia-, creemos, es el Principio Fundamental de la actuación de Dios y de Jesús, y debe serlo de la Iglesia. Es una acción para erradicar el sufrimiento, movidos por el no deber ser del sufrimiento. Así, si es preciso, se juega sin escapatoria el propio ser. Este es el centro de la acción de Jesús y la del Dios que nos revela.

La «Compasión-misericordia» entendida desde estos dos enfoques, nos coloca de cara al atroz sufrimiento de las víctimas del desplazamiento forzado. Optar por este principio rector de nuestro actuar, es iniciar un camino exigente y novedoso, abiertos a la interacción con otras miradas que se están haciendo el mismo planteamiento en Colombia. La argumentación de nuestras categorías de investigación habla de este propósito incipiente en el país, pero que se constituye en el comienzo de una mirada y de una acción urgente y necesaria.

\subsubsection{El pretexto de Jesús de Nazaret se forma en sus entrañas conmovidas como las de su Dios}

Jesús anuncia el Reino pero desde un lugar concreto: las entrañas conmovidas de Dios por los más pobres. Por ello, su primera mirada está dirigida a los que sufren. Ellas/os son los primeros destinatarios del anuncio de la llegada del Reino (Lc 4, 16ss.). El movimiento de Jesús les incorpora como sujetos sufrientes a un proyecto de vida plena y abundante (Jn 10,10). Esta inclusión no es bien recibida por los poderes judíos y su discipulado es visto como movimiento de «hondo fastidio» para los intereses del imperio.

57 Cf. Ernst Bloch, El principio esperanza (Madrid: Trotta, 2004). 
Movimiento conformado por «don nadies» ${ }^{58}$, con inusitada capacidad transformadora y perturbadora del orden social y político romano. Desde este horizonte miramos hacia las víctimas. La sola razón de la existencia de su sufrimiento nos mueve a comprometernos con la transformación de esa situación como imperativo ético inaplazable.

Colombia padece una situación que exige este movimiento de compasión misericordiosa. No es el espacio para describir dicha situación pero basta señalar la «realidad apabullante» ${ }^{59}$ que azota al país: la existencia de 5,5 millones de víctimas en el territorio nacional, en medio de la más compleja problemática sociopolítica y de la más inexplicable indiferencia de los connacionales. Se comienza a reconocer como causa principal del problema de su violencia interna, la tragedia de la tierra, su concentración y expropiación. La Ley de Víctimas y de Restitución de Tierras es una muestra de lo que comienza a pasar en el país ${ }^{60}$. El Proceso de Paz que adelantan el gobierno nacional y las Farc ha puesto este punto como el primero de la agenda de negociaciones.

En esta situación desgarradora que vive Colombia y de la que no puede ser ajena la pastoral de la Iglesia, expresiones como estas han de resonar en cualquier plan de acción: «coraje del perdón», «el derecho a saber la verdad», «que otros se sensibilicen con el dolor ajeno», «creación de espacios para compartir el dolor», «recuperar la historia», "desactivar el tema del odio», «la sociedad colombiana debe iniciar el proceso de mirarse a sí misma», "estamos ante la responsabilidad de preparar el posconflicto», «preparar el escenario de encuentro entre víctimas y victimarios: sin perdón no es posible la reconciliación», entre muchas otras que podríamos formular.

Por todo esto, la pertinencia de nuestra mirada desde el Principio compasión-misericordia, eje de convergencia de nuestras categorías de análisis, nos coloca en sintonía con estos aspectos, con los cuales

\footnotetext{
58 John Dominic Crossan, Jesús: biografía revolucionaria (Barcelona: Grijalbo Mondadori, 1996), 70.

59 Revista Semana, proyecto Víctimas, op. cit.

60 Juan F. Cristo, La guerra por las víctimas (Bogotá: Ediciones B, 2012).
} 
nos ubicamos en el mismo horizonte de opción por los sujetos sufrientes. Se abre un escenario de aportación a la reconstrucción de la sociedad civil en Colombia. Crear esta interlocución es tarea urgente e irrenunciable.

3.3.2 Creación de un nuevo lugar epistemológico para abordar el drama del desplazamiento forzado en Colombia.

El principio compasión misericordia y el concurso de otros enfoques interdisciplinares y sociales nos sitúan en la necesidad de partir de un nuevo lugar epistemológico desde donde podamos responder a la situación del desplazamiento forzado en Colombia. Nuestras categorías de investigación se mueven para ello posicionando la categoría «lugar», desde una semántica amplia que reivindique diferentes maneras de comprender la tragedia de los victimizados en Colombia y visibilice su condición sufriente. Así, esta concepción de lugar, no necesita que sea físico o geográfico, también puede ser social, mental o ideológico ${ }^{61}$. El lugar se construye desde enfoques diversos e integra una visión holística del drama de los sujetos desplazados, cuyo efecto es generar reconocimiento en la sociedad de su situación y, a la vez, construir sus espacios con nuevos significados. También deconstruye lugares «intocables», bien sean espacios sociales, ideológicos o geográficos, en los que una presencia dominante les impedía ser o estar. Es la posibilidad de la existencia de un «no lugar», en el sentido de una «desubicación» del efecto de la influencia dominante ${ }^{62}$. Moverse entre un «no lugar», como espacio de rechazo y dominación y entre lugares que aún no lo son, habla del reto de crear nuevos significados, en nuevos espacios que indican dinámicas de transgresión y traslación tanto ideológicas como físicas. Es el caso de Jesús de Nazaret y su grupo de seguidores/as, en una posición alternativa de construcción de identidad ${ }^{63}$. Abrir este

61 Halvor Moxnes, Poner a Jesús en su lugar, una visión radical del grupo familiar y el reino de Dios (Estella: Verbo Divino, 2005), 40.

62 Ibíd., 97-106.

63 Ibíd., 108-110. 
camino nos compromete con una acción pastoral nueva, convergente en el corazón mismo de la compasión-misericordia, para que este sufrimiento no sea más y para que todas las fuerzas posibles se unan en una praxis liberadora.

Este nuevo lugar es un ejercicio imperativo en el proceso de visibilización y ubicación espacial con sentido, de nuestros sujetos desplazados ${ }^{64}$ y puede formularse con los siguientes enunciados:

- Reconocer que los sujetos sufrientes además de ser desplazados forzados, también son desterrados, expulsados y agredidos de manera injusta. Limitarnos a llamarlos desplazados, oculta el carácter violento de su salida que incluye la expropiación de la tierra y eventos violentos tales como masacres, torturas, violación sexual, entre otras tantas vejaciones, que afectan de manera radical a la población civil y la obliga a dejar de manera abrupta e inesperada su casa, su vida y su cultura ${ }^{65}$.

- En Colombia se ha venido usando la expresión «reparación de las víctimas», como uno de los senderos a seguir en los procesos internacionales de justicia transicional que se busca instaurar en el país. La afirmación la consideramos afortunada porque posiciona a los sujetos sufrientes desplazados en un reconocimiento nacional frente a la tragedia histórica de que han sido objeto. Para ello, la recuperación y preservación de la memoria es clave, en cuanto a través de la mediación de la reflexión académica se mantiene la historia propia y se evitan los peligros del olvido declarado ${ }^{66}$. Se escudriña el pasado para no perder las raíces de la identidad. Así se busca superar el sufrimiento como una forma de pensar en el futuro, no para instalarse en el

64 La ubicación espacial con sentido, también incluye el lugar geográfico. En él confluyen todos los demás sentidos de lugar. Se crea un significado que da identidad, arraigo, apropiación, empoderamiento.

65 Carlos Enrique Angarita, Cuando se hacía la fiesta todos vivíamos en comunidad. Comunidades en destierro, narraciones para una espiritualidad del peregrino (Bogotá: Pontificia Universidad Javeriana, 2007), 19

66 Clara Inés García, «Subjetividades bajo la violencia. Una perspectiva desde la sociología». En José Fernando Velásquez et ál. Conflicto armado: memoria, trauma y subjetividad (Medellín: La Carreta Editores, 2008), 65. 
«malestar que puede terminar en retaliación, sino de conceder a la memoria una salida que aligere la carga de pesar venida de siniestros acontecimientos pasados $»^{67}$. Es también la manera de ir abriendo paso en la sociedad civil de una sensibilidad humana y social ante las víctimas que no existe, lo que impide pensar en colectivo este drama de los sufrientes tan particularizado, tan ajeno a la solidaridad nacional.

- La compasión, cuyo lugar ya hemos expuesto, es razón sin la cual no hay ni verificación ni educación de la memoria. Desde este enfoque se hace imperativo ético nacional, la medida del sentir con los demás. Estas convergencias nos llevarán a ello. El cometido integrador va tomando forma: no olvidar el sufrimiento de las víctimas. El aporte de esta investigación tiene este centro irrenunciable.

- Desde la autoridad de los que sufren, estamos ante un proceso muy complejo en Colombia de diferenciación e identificación entre las víctimas y los victimarios. Si no hay procesos de verdad, justicia y reparación, sin lugar a la impunidad, la sociedad civil puede pasar de largo con la excusa de la dolorosa clasificación de las víctimas en reales y difusas ${ }^{68}$. Nuestro acompañamiento requiere la denuncia de este peligro, sensibilizando a las comunidades de la degradación ética en que incurre el país si continúa de espaldas a esta realidad de sufrimiento. Esta autoridad nos impulsa a entrar en el desafío de situar a las víctimas en el espacio de lo público y de lo colectivo, lo que significa trabajar por «reconocerlas como actores centrales del conflicto, como sujetos políticos con derechos conculcados y pisoteados, que es necesario restablecer y restaurar hasta donde ello sea posible, como ciudadanos y ciudadanas que tienen palabra y capacidad de acción y cuyas demandas deben ser tenidas en cuenta a la hora de las negociaciones y de los acuerdos de paz. En otras palabras, reconocimiento y acción política es el 
nuevo estatus de las víctimas y su participación activa en el diseño de las posguerras» ${ }^{69}$. Desde nuestro presupuesto teológico, estar al margen, sin un mínimo diálogo con esta realidad, es incoherente e inadmisible para nuestra fidelidad a Jesús de Nazaret y su proyecto misericordioso.

- La categoría género ${ }^{70}$ ha ganado carta de ciudadanía en la sociedad contemporánea. Es parte importante en el desarrollo de la crisis del paradigma vigente, o del cambio en la cosmovisión imperante, como una apertura a lo nuevo y también desconocido. Este enfoque es fundamental en la construcción simbólica del lugar, como lo venimos exponiendo. La ruptura del paradigma de la formación de lo femenino y lo masculino en el contexto de la guerra colombiana será decisiva, en el sentido de facilitar la dignificación de las/os sujetos sufrientes en desplazamiento, su reparación y reincorporación a la sociedad. Es necesario un nuevo proceso de reconstrucción sociocultural de lo femenino y lo masculino. Feminidades y masculinidades en relación de iguales. Es una contrarrespuesta a la degradación que el conflicto armado ha puesto en la mujer como objeto sexual y botín de guerra. Trabaja por la reivindicación de lo femenino y sus alternativas de humanización del conflicto.

Propende por la desarticulación de la dominación masculina en el contexto violento que, en casos como la zona Caribe, ha tenido tintes escandalosos:

La violencia sexual contra las mujeres, además del acceso carnal violento, se ejerció, entre otras formas, mediante la desnudez forzada, la tortura sexual, el establecimiento y exigencia de pautas de relación entre hombres y mujeres en el ámbito afectivo y sexual, y la esclavitud sexual y doméstica. Es posible afirmar que hay en este tipo de manifestaciones una direccionalidad de género, es decir,

69 Ibíd., 67

70 Para una profundización en la categoría género Cf. Marta Colorado López; Liliana Arango Palacio; Sofía Fernández Fuente, Mujer y feminidad en el psicoanálisis y el feminismo (Medellín: Imprenta Departamental, 1998). Darío García, Consuelo Vélez, Socorro Vivas, Reflexiones en torno al feminismo y al género (Bogotá: Pontificia Universidad Javeriana, 2004). 
la violencia infligida contra las mujeres en gran medida estuvo asociada a la transgresión de los arreglos de género o definiciones de hombre y mujer, que tuvieron gran centralidad en el proyecto de orden paramilitar en el norte de Colombia. Acciones adicionales que apuntaban a la consolidación de este orden paramilitar eran el asesinato selectivo de mujeres líderes o contestatarias, las restricciones a la movilidad y a la sociabilidad, y el confinamiento de muchas de sus actividades en el ámbito privado ${ }^{71}$.

Es nada más un ejemplo, de la manera como se ha instalado la violencia de género en la situación colombiana, por medio de un montaje patriarcalista, asociado a la imagen ruda del galán violento, latifundista colombiano.

- La interacción entre el sujeto en movilidad y el escenario de acogida suscita problemas no solamente del orden de la interacción de las personas sino de falta de reconocimiento del otro en el espacio próximo compartido; el espacio no es solo una autoevidencia de lo positivo, de lo que está frente a mí, sino que tiene implícito un interrogante sobre la naturaleza de la relación entre el hombre y el mundo ${ }^{72}$; desde esta perspectiva se puede comprender lo corpóreo, como una modalidad de la relación entre el espacio, las cosas y los sujetos, la cual trasciende al cuerpo y no asume exclusivamente su dimensión material, en donde se descubriría como otras de las cosas del mundo ${ }^{73}$.

Sobre sus arrugas -las del cuerpo, por ejemplo- se inscriben el tránsito interminable de recuerdos y lugares por los que anduvo. Sus arrugas son esa historia, el efecto de ese tránsito a través de anteriores encuentros sedimentados en la memoria. En este sentido, además de arrugas o manos, en sentido propiamente orgánico, que «de suyo» son manos y arrugas, están «incorporadas»y apropiadas subjetivamente ${ }^{74}$.

- La reconstrucción social de las subjetividades sufrientes implica la defensa de la dignidad del sujeto mujer y varón,

71 Informe del Grupo de Memoria Histórica de la Comisión Nacional de Reparación y Reconciliación. Mujeres y guerra (Bogotá: Edición conjunta Altea, Taurus, Alfaguara, Ediciones Semana, 2011), 19. Alejandro Castillejo, op. cit., 97.

Ibíd., 98.

Ídem. 
agredido por el conflicto, hecho sufriente por las condiciones del desplazamiento forzado. En esta acción habría que partir de la «singularidad del sujeto social» ${ }^{75}$. Es el sujeto capaz de participar en la elaboración de la acción social porque interactúa con las estructuras sociales en las que está inserto y que le generan un «campo de posibilidades» para la construcción de la subjetividad $^{76}$. Aquí es posible construir sentido e identidad en el movimiento entre el sujeto personal y el sujeto colectivo. Vienen elementos tales como «comprender procesos de integración social, de conflicto o de violencia, o aportar en procesos de intervención social en los que se busque, por ejemplo, solución de conflictos, interlocución entre actores, construcción de consensos, políticas de memoria, etc. $\rangle^{77}$. En este proceso, nuestro acompañamiento a las víctimas de desplazamiento forzado, en cuanto han vivido la agresión de un antisujeto ${ }^{78}$, nos lleva a distinguir entre la identificación negativa que ellas hacen de su condición como "humilladas y destruidas, sin que esa identidad aporte una exigencia para el futuro» ${ }^{79} \mathrm{y} \mathrm{su}$ identificación con una exigencia en el futuro. «Este es el caso que debe convocar al trabajo con víctimas: lograr acompañar, desencadenar y coadyuvar en su proceso de subjetivación» ${ }^{80}$. Este procedimiento se integra muy bien desde la construcción de lo colectivo en lo público, con la formación del lugar y el afianzamiento de una territorialidad emergente para las y los sujetos en desplazamiento en la gran ciudad. A través de la mediación sociológica es posible asumir este reto desde nuestro quehacer teológico y pastoral.

Clara Inés García, op. cit., 28.

Cf. Ibíd.

Ibíd., 29.

El que desubjetiviza al otro y lo hace instrumento de su crueldad sin límite. Ibíd.., 30.

Ibíd., 31.

Ídem. 


\section{Pistas de acción para una pastoral suburbana en articulación con la realidad del desplazamiento forzado}

La presente investigación es, apenas, una puerta de entrada al mundo del desplazamiento y a los desafíos para una pastoral suburbana que quiere responder profética y eficazmente a estos «gritos del Espíritu» para que la acción evangelizadora toque fibras internas y se convierta, ahora sí, en buena noticia anunciada y vivenciada en y para los/as excluidos/as y empobrecidos/as, que son las personas en situación de desplazamiento por la violencia social, política, represiva o subversiva que desangra a nuestro país desde hace años. Plantear una pastoral suburbana para los sujetos sufrientes cuya vida se caracteriza por la liminalidad y la ambigüedad rompe con los programas masivos, estandarizados e inamovibles que en general ofrecen las parroquias de las grandes urbes.

La gran ciudad nos plantea la pregunta por el quehacer de la Iglesia, frente a tantos sujetos sufrientes que se atrincheran en las fronteras de la ciudad y de quienes desconocemos su existencia. ¿Cómo podemos ser comunidad, ser Iglesia cuando hay miles y miles de seres humanos que son invisibilizados, y desconocidos hasta por nuestras mismas organizaciones? ¿Cómo podemos hablar de afirmarnos nosotros cuando no afirmamos primero el tú de esa inmensa mayoría de población? La conciencia de sí -solo es posiblesi hay, primero, conciencia de otro; la existencia de un yo es factible si existe el otro. Se trata en este caso de una interacción, de un encuentro intersubjetivo, pues depende del reconocimiento de la existencia toda, material y subjetiva del otro, de afirmar la absoluta necesidad de que el otro sea para que yo también pueda ser.

Desde aquí nos proponemos delinear algunas orientaciones pastorales que pueden caracterizar una pastoral suburbana que atienda la realidad de los sujetos de las periferias de las grandes ciudades. Para el caso concreto de la ciudad de Bogotá, esos sujetos 
sufrientes, en su mayoría son víctimas del desplazamiento y esperan una ayuda eficaz por parte de la Iglesia. Creemos que la pastoral suburbana no puede ser ajena a este desafío.

Pero es una tarea a la que nos comenzamos a aproximar con las propuestas que señalamos a continuación:

Esta investigación nos ha llevado a constatar la necesidad de realizar un trabajo interdisciplinar para comprender bien la realidad a la que nos enfrentamos: la de las personas víctimas de desplazamiento en la realidad colombiana. No hemos conseguido realizar esta aproximación pero consideramos que es una tarea pendiente. Sin embargo, reconocemos que las categorías de análisis que han guiado nuestra investigación son una puerta de entrada para ese diálogo interdisciplinar. De hecho, partir de las subjetividades sufrientes, la recuperación de la memoria, el cuerpo -entendido como territorio, memoria, narración-, la perspectiva de género y el desplazamiento, es señalar categorías a las que hay que aproximarse desde otras disciplinas tales como sociología urbana, antropología cultural, psicología social, pedagogía social, filosofía política, etc. Por tanto, se necesita entablar un diálogo con ellas para comprender mejor la realidad considerada. De esta constatación surge una propuesta muy concreta: la pastoral suburbana que asume realidades tales como el conflicto armado colombiano, no puede plantearse sin el concurso de esa mirada interdisciplinar y tampoco puede hacerse sin asumir aspectos tan importantes de esa realidad tales como la ley de víctimas y restitución de tierras, la justicia transicional -verdad, justicia-reparación- a la que proponemos añadir «la reconciliación», desde el punto de vista creyente, como un aporte específico que debemos hacer. En efecto, la reconstrucción sociopolítica de Colombia implica la presencia de muchas instancias -no solamente creyentes- porque es entre todos que se puede reconstruir el país y la sociedad. Todo esto queda como un desafío que no alcanzamos a responder en esta investigación, pero que nos pone en el horizonte del conflicto colombiano y que se torna una exigencia para toda pastoral urbana que quiera asumir en serio la dignificación de las subjetividades sufrientes. 
El proceso de transformación territorial de la urbe influye decisivamente en las personas y, mucho más, en las personas en situación de desplazamiento. Esto nos lleva a enfrentar lo que podemos denominar «nuevas territorialidades» que suponen toda la dimensión existencial que constituye a los sujetos y que se realiza en esa historia personal que implica dejar una cultura para asumir otra; llevar en el propio cuerpo inscritas las experiencias dolorosas y aprender a desplazarse de la periferia al centro para poder sobrevivir. A las personas en situación de desplazamiento se les arranca de un lugar y es muy difícil encontrar otro que reemplace lo que perdieron. Esas experiencias hacen que la territorialidad vaya más allá de lo geográfico y a este aspecto es al que queremos referirnos. La pastoral suburbana ha de asumir nuevas territorialidades, esas territorialidades «existenciales» que implican a toda la persona y que constituyen a los sujetos. Las nuevas territorialidades son nichos de vida alternativos en los que llevamos a cabo esta misión urbana. Son resignificación de los lugares que se han convertido en «no lugar», agravando la situación de los desplazados. Esto está en relación estrecha con el oikos-oikía (oĩcós-oikía $\alpha$ casa). Hace parte de la ruptura que habría que hacer con la convencional concepción territorial de la parroquia, generando un nueva eclesialidad a tono con el movimiento urbano de la ciudad.

Una realidad muy clara que hemos encontrado es que existen muchas organizaciones de la Iglesia y del Estado que responden a la situación de desplazamiento. Algunas tienen articulación pero muchas otras no. El desafío que nos surge es la urgencia de sumar fuerzas para superar un nivel de asistencialismo y pasar a un nivel de reconstrucción de sujetos. Esto nos lleva a proponer para la pastoral suburbana, el impulsar estas articulaciones, el buscar que las fuerzas se multipliquen por una acción coordinada y eficaz. No quiere decir que desde la Iglesia se lidere este proceso de atención al desplazado -sería algo que supera las fuerzas- pero que se tenga como un horizonte en el que se planteen las líneas de acción de la pastoral suburbana que proponemos impulsar. 
Abordar un problema tan complejo como es el fenómeno del desplazamiento no puede asumirse desde lo que hemos llamado «pastoral de conservación» o del esquema tradicional de parroquia. Hemos de tomar en serio la urgencia de transformación pastoral que parta de otra «episteme» - a la que nos pueden orientar de manera significativa las categorías que hemos formulado en esta investigación- para formular una pastoral suburbana que responda

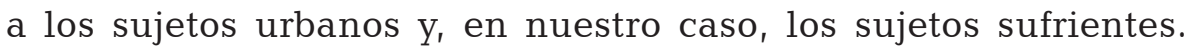
Categorías como «memoria», "principio compasión misericordia», «género», etc., dan otra orientación a la pastoral y posiblemente posibiliten esa «conversión pastoral» propuesta por Aparecida. De esa manera se responde a las necesidades de la gente y se deja de lado el modelo de pastoral tradicional que ofrece servicios religiosos y no toma en cuenta la necesidad concreta de los destinatarios.

El «principio compasión misericordia» no es una categoría más entre otras categorías eclesiales, sino que la colocamos en el centro del actuar eclesial porque ella ha de mostrar su capacidad de «detenerse ante los caídos en el camino», pero dándole nombre, lugar, situación, realidad. No basta con invocar el principio "misericordia» en general, o una vivencia de las tradicionales «obras de misericordia», sino que aquí nos referimos a las situaciones de inhumanidad que atraviesan hoy nuestro mundo y que en el caso colombiano, las viven las personas en situación de desplazamiento. Esa realidad no es un fenómeno puntual, sino un problema fundamental que ha de asumirse para pensar la reconstrucción del país y que no puede quedar al margen de una pastoral suburbana.

Es un proceso identitario, acompañado por la práctica pastoral del seguimiento de Jesús. Es la acción política de la pastoral de la misericordia, que se plasma en el compromiso por lo humano, alimentada en el «amor político»" ${ }^{81}$, esto es, el que busca la vida, la libertad y la justicia. Esto genera conflicto con los sujetos dominantes, «dueños»

81 José M. Mardones, Fe y política. El compromiso político de los cristianos (Santander: Sal Terrae, 1993), 70. 
del territorio, por el empoderamiento de los sujetos en inserción en este proceso pedagógico de la misericordia. La postura de nuestros sujetos emergentes es, así, menos desigual, o con más capacidad de defensa y autodeterminación ${ }^{82}$. Esta acción, sin embargo, no es limitada, su simbólica es amplia, el proceso de identificación de los sujetos goza de amplias posibilidades de proyección e interacción con la contextualidad urbana.

Territorialidades existenciales ${ }^{83}$ : una vez concebida la casa como lugar de múltiples significaciones, procedemos a entrelazar en medio de los contextos urbanos nuestros oikos-oikías ${ }^{84}$, en la expansión de la apropiación social y cultural de los espacios ganados, en los que, desde nuestra visión de género, alimentamos una significativa presencia de la subjetividad. A esto llamamos territorios existenciales. Nuestros sujetos victimizados se van convirtiendo en sujetos emergentes y urbanos, protagonistas de nuevas experiencias humanas llenas de sentidos, de significaciones, de lenguajes y producciones simbólicas. Se da una apropiación del espacio con las interacciones entre personas, una construcción social e histórica que va dando identidad. El territorio existencial es, en consecuencia, la suma de estos factores que va superando el espacio físico, hasta convertirse en lugar vital. Cuando este proceso se consolida, es territorio marcado, posicionamiento y empoderamiento de presencias en la ciudad, que se abren paso en la superación de la anomia social (su invisibilidad por la indiferencia y el desconocimiento). El gran reto de la pastoral de la misericordia con las/os sujetos en desplazamiento, es la construcción de estas territorialidades en el marco de la expansión urbana y sus efectos invisibilizadores de la condición dramática de los desplazamientos en la gran urbe. Es un esquema a tono con las transformaciones de la ciudad, con los cambios epocales y con las exigencias de los nuevos derroteros de las

82 Halvor Moxnes, op. cit., 39-41.

83 Expresión trabajada por Oscar Useche, op. cit.

84 Comprensión tomada de: John H. Elliot, Un Hogar para los que no tienen patria ni hogar, estudio crítico de la carta primera de Pedro y de su situación y estrategia (Estella: Verbo Divino, 1995), 61. 
ciudades empeñadas en la sostenibilidad humana y ambiental. Para estos nuevos sujetos, ya no habrá más un «no lugar», en medio de la ambigüedad y lo liminal, al margen de un «orden establecido» ${ }^{85}$, en la medida en que son protagonistas de la conquista de una nueva ciudadanía ${ }^{86}$. Con todo, la apropiación de la territorialidad a través del proceso señalado, no puede desconocer las dinámicas actuales que desestabilizan la tradicional relación ciudadanía-Estado nacional, imponiendo la emergencia de la ciudad global, causa de una nueva concepción del orden político y de las relaciones sociales ${ }^{87}$.

Aunque este fenómeno imponga una desterritorialización, no estamos lejos de responder, aprovechando las relaciones emergentes entre lo local y lo global, a la construcción de un nuevo sistema de relaciones, alternativo a la desaparición de los sujetos en este nuevo entramado, que no desterritorializa todo, incapaz de frenar dinámicas como la autoridad de los que sufren. Es nuestra inscripción en la red mundial por la dignificación de los marginados.

La pastoral suburbana tiene unas fuentes documentales de gran riqueza y pertinencia para el momento actual. Actualizar los contenidos de los documentos eclesiales, especialmente, la Gaudium et Spes y las Conferencias Episcopales Latinoamericanas, es recuperar esos orígenes que abrieron las puertas a la reflexión sobre pastoral urbana y llevar adelante sus propuestas. No está todo dicho pero ya hay un camino recorrido que es importante llevarlo a la práctica, actualizándolo a cada realidad concreta. Las megalópolis -término que introdujo Pablo VI- revelan esta situación de migraciones, especialmente de los terceros mundos, pero que en la realidad colombiana adquieren un tono mucho más grave porque la migración es forzada, el rompimiento con su tierra es obligado y lleno de dolor, temores y violencia.

85 Cf. Marc Augé, Los no lugares. Espacios del anonimato. Una antropología de la sobremodernidad (Barcelona: Gedisa, 2008).

86 Saskia Sassen, Contrageografías de la globalización. Género y ciudadanía en los circuitos transfronterizos. Traficantes de Sueños (Madrid: Publidisa, 2003), 87.

87 Ibíd., 88 
La perspectiva de género nos desafía a responder a las necesidades concretas de los varones y mujeres en las grandes urbes pero, especialmente, a contribuir desde ahí en la reconstrucción de los sujetos urbanos y que no admiten estereotipos culturales que oprimen y no contribuyen a la verdadera liberación de las personas.

La formulación de una teología política desde las víctimas es una propuesta concreta para responder al sufrimiento de tantas personas que en las grandes urbes sufren el maltrato, la opresión y tantas otras situaciones que impiden su desarrollo integral.

Es un reto la reconstrucción/sanación del cuerpo de los varones y mujeres en su dimensión personal y social, porque en sus cuerpos queda inscrita la memoria del sufrimiento vivido y la sanación ha de alcanzar a toda su realidad de manera integral.

La interacción entre la pastoral suburbana y la pastoral bíblica nos resulta muy iluminadora y fundamental. En esta investigación hemos partido de la Parábola del Buen Samaritano y más adelante una pastoral de la misericordia al servicio de la gran ciudad, pero abarca mucho más. La Palabra de Dios tiene la capacidad de iluminar la realidad de las ciudades y ofrece una respuesta a las situaciones que se viven. Esta iniciativa es algo que ya se está llevando a cabo en un proyecto llamado «Casitas bíblicas»" ${ }^{88}$, que ha permitido que personas de la marginalidad encuentren en la lectura de la Palabra sentido a las situaciones que viven y fuerza de acción para la transformación de su realidad. De esta manera la pastoral bíblica ha de ser transversal a la pastoral suburbana, pero a su vez la pastoral suburbana invita a los sujetos intérpretes de la Biblia a leer su realidad urbana desde ella y encontrar sentido y valor a su compromiso social. En este sentido, se ha de propiciar una «lectura

88 Es una experiencia de lectura urbana de la Biblia en contextos marginales, nacida en el suroriente de la ciudad de Bogotá en el año 1991. Ha logrado generar una participación diversa desde la perspectiva intercultural, intereclesial y desde las realidades de sufrimiento de esas personas. Nació en el seno de una parroquia católica pero se ha ido convirtiendo en un movimiento ecuménico que contribuye a humanizar esas situaciones límite, en concreto, muchas personas en situación de desplazamiento, que han llegado a esa zona. Para mayor información cfr. http://casitasbiblicas.blogspot.com/. 
urbana» de la Biblia que ayude a las personas a iluminar su realidad y a responder a ella desde la fe.

Un aspecto importante es entender la situación de desplazamiento que hemos trabajado en la investigación. Para el teólogo John Elliot, en el análisis socioreligioso que hace de la primera carta de Pedro,

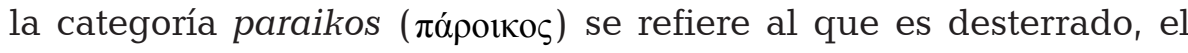
extranjero que está fuera de su patria, el que no tiene raíces, no conoce bien la lengua, las costumbres, ni la cultura del país, por lo que es sometido y sufre opresión ${ }^{89}$. La categoría nos sirve para designar a los sujetos en desplazamiento, que viven en similar situación. Lo contrario de paroikos es oikos-oikía que significa en mi casa, en mi hogar, con mi grupo, mi linaje, mi identidad, el lugar al que pertenecemos. La pastoral suburbana que asume como tarea responder a las personas en situación de desplazamiento, ha de ayudar a pasar del paroikos al oikos-oikía, de ser exiliado a reconstruir una casa, un hogar, una comunidad, una red de relaciones que les permita reconstruir su identidad personal y su mundo de relaciones brutalmente truncado por la violencia que han vivido. Las categorías de cuerpo, memoria, género, etc., contribuyen a esa restitución de la dignidad y a un tejer nuevas relaciones que les ayuden a tener raíces, referencia, origen social. Esta es una alternativa a la pastoral parroquial tradicional que, según los mismos desplazados, no les ofrece una respuesta adecuada.

A partir de la parábola del Buen Samaritano, proponemos algunas líneas de acción pastoral que pueden configurar una pastoral urbana que atiende también a las personas en situación de desplazamiento. Partimos del principio compasión misericordia pero tomamos en cuenta diversos aspectos de la parábola, así: (1) «El samaritano se acerca y ve, se baja del caballo, cura sus heridas»: la pastoral suburbana debe acercarse a los caídos en el camino y ver su situación. No un ver de espectador sino un ver que se implica y se compromete (2) «venda sus heridas y cura al herido con vino y 
aceite»: puede referirse a ese culto nuevo «en espíritu y verdad» que atiende las necesidades de las personas y no se limita a ofrecer la pastoral de sacramentos que tradicionalmente se vive. (3) «cargar con el herido»: no solo lo cura sino que lo levanta, lo carga y lo lleva a la posada. Todo esto sugiere acciones de acompañamiento que van más allá del asistencialismo y se mueven más por lo central de la parábola: la compasión ( $\sigma \pi \lambda \alpha \gamma \chi \nu i \zeta$ o $\mu \alpha \iota)$ que brota de las entrañas, que las remueve, que sitúa la misma compasión desde dentro como lo experimenta, desde dentro, Dios mismo. Es decir, el acercarse al otro no es una acción más sino un movimiento de fraternidad/sororidad que surge de las entrañas, desde el mismo corazón de Dios. De otro lado, nos ubica en el encuentro con una imagen de Dios diferente, la que nos muestra Jesús, la de un Dios de entrañas conmovidas. Este es el Dios que realmente «habita la ciudad». La pastoral suburbana tendría que comprometerse seriamente con la consideración de esta imagen de Dios que, hace parte de la complejidad desafiante a la que asumimos responder. Es decir, la imagen de Dios es otro de los vacíos pastorales y teológicos que conforman el escenario religioso en el cual se mueven los desplazados, como sujetos sufrientes.

Precisamente, una pastoral suburbana con población en situación de desplazamiento exige que los agentes de pastoral de las comunidades y parroquias se involucren en la acción política de defensa de los derechos humanos. No solo asistir, sino acompañar a las personas en sus tortuosos y quebradizos caminos de reclamación y afirmación de sus legítimos derechos. Esto supone romper con el viejo paradigma de la pastoral apolítica; una pastoral urbana con estos sujetos específicos exige formación y compromiso político, desde el evangelio, desde el magisterio social de la Iglesia, desde una teología en contexto y una pastoral liberadora.

Implica y exige también, una conversión intelectual, moral y religiosa ${ }^{90}$ de los agentes de pastoral. Intelectual porque se hace urgente

90 Bernard Lonergan, Método en teología (Salamanca: Sígueme, 1994), 231-238. 
un cambio epistemológico que permita comprender la complejidad del fenómeno del desplazamiento y se quiera responder a él desde una perspectiva interdisciplinar, moral porque es imperativo ético afrontar esta realidad del país y nadie puede quedar por fuera y religiosa, porque la experiencia del Dios de Jesús ha de comprometernos con los caídos en el camino y, para la realidad colombiana, el desplazado es un verdadero herido frente al cual hemos de empeñar todas nuestras acciones pastorales para transformar su situación.

Finalmente, la vida eclesial celebra en la liturgia su fe. En la pastoral suburbana a la que nos hemos referido, la liturgia ha de ser expresión de un compromiso total y a fondo como el del Buen samaritano, donde se note que por la fe, la situación del país nos duele, nos compromete y activa lo mejor de nuestros recursos pastorales para salir al encuentro de esas situaciones.

\section{Bibliografía}

Angarita, Carlos Enrique. Cuando se hacía la fiesta todos vivíamos en comunidad. Comunidades en destierro, narraciones para una espiritualidad del peregrino. Bogotá: Pontificia Universidad Javeriana, Facultad de Teología, 2007.

Augé, Marc. Los no-lugares. Espacios del anonimato. Una antropología de la sobremodernidad. Barcelona: Gedisa, 2008.

Bello, Martha. Las familias desplazadas por la violencia. Un tránsito abrupto del campo a la ciudad. Ponencia presentada al Congreso Internacional: Cultura, Familia y Sociedad. Bogotá: Universidad Nacional de Colombia, mayo de 1998.

Bloch, Ernst. El principio esperanza. Madrid: Trotta, 2004.

Caramuru, R. «Informe general». En Caramuru R. et ál. La Iglesia al servicio de la ciudad. Barcelona: Nova Terra-Dilapsa, 1967.

Casitas bíblicas. Consultada en mayo 15, 2013. http://casitasbiblicas. blogspot.com/. 
Castillejo, Alejandro. Poética de lo otro. Para una antropología de la guerra, la soledad y el exilio interno en Colombia. Bogotá: ICANH y Colciencias, 2000.

Celam, III Conferencia General del Episcopado Latinoamericano Puebla. Consultada en septiembre 19, 2011. www.celam. org/conferencia_puebla.php.

. IV Conferencia General del Episcopado Latinoamericano Santo Domingo. Consultada en septiembre 19, 2011. www. celam.org/conferencia_domingo.php.

- V Conferencia General del Episcopado Latinoamericano Aparecida. Consultada en septiembre 19, 2011. www.celam. org/conferencia_aparecida.php.

CODHES. Boletín Informativo N. ${ }^{\circ} 77.2011$, consultada en septiembre 15, 2012 www.rebelion.org/docs/130767.pdf.

. Boletín Informativo N. ${ }^{\circ} 75,2009$. Consultada en septiembre 25, 2012. www.cambio.com.co/media/produccion/CrisisHumanitaria/pdf/l2.pdf.

Colorado López, Marta; Arango Palacio, Liliana; Fernández Fuente, Sofía. Mujer y feminidad en el psicoanálisis y el feminismo. Medellín: Imprenta Departamental, 1998.

Cristo, Juan F. La guerra por las víctimas. Bogotá: Ediciones B, 2012.

Crossan, John Dominic. Jesús: biografía revolucionaria. Barcelona: Grijalbo Mondadori, 1996.

Declaraciones sinodales 1998. Plan Global de Pastoral. Arquidiócesis de Bogotá. 1999-2008. Bogotá: Publicaciones de la Arquidiócesis de Bogotá, 1998.

Elliot, John Hall. Un hogar para los que no tienen patria ni hogar. Estudio crítico social de la carta primera de Pedro y de su situación y estrategia. Estella: Verbo Divino, 1995.

Entrevista a profundidad. Consultada en mayo 7, 2013. http://es.scribd. com/doc/6904791/Entrevista-de-Profundidad\#download. 
Fernández, Amelia y Gutiérrez, Diego. «Proyecto Vidas Móviles: Caracterización de las poblaciones en situación de desplazamiento y vulnerable receptora en la localidad de Ciudad Bolívar». Revista Universitas Médica 50 (2009): 4157. Consultada en mayo 25, 2013. www.redalyc.org/articulo. oa? id $=231018725004$.

Fitzmyer, Joseph. El evangelio según Lucas, III, traducción y comentario 8, 22-18, 14. Madrid: Ediciones cristiandad, 1978.

Floristan, Casiano. Teología práctica, teoría y práctica de la acción pastoral. Salamanca: Sígueme, 2002.

Galli, Carlos María. Dios vive en la ciudad. Hacia una nueva pastoral urbana a la luz de Aparecida. Buenos Aires: Ágape Libros, 2012.

García, Clara Inés. «Subjetividades bajo la violencia. Una perspectiva desde la sociología». En Velásquez, José Fernando et ál. Conflicto armado, memoria, trauma y subjetividad. Nueva escuela Lacaniana. Medellín: La Carreta Editores, 2008.

García, Darío; Vélez, Consuelo y Vivas, Socorro. Reflexiones en torno al feminismo y al género. Bogotá: Pontificia Universidad Javeriana, 2004.

Grupo focal. Consultada en mayo 7, 2013. http://es.scribd.com/ doc/74110812/Que-es-el-grupo-focal\#download.

Informe de la Agencia de la ONU para los refugiados. Consultada en junio 20, 2013. www.acnur.org/t3/operaciones/situacioncolombia/desplazamiento-interno-en-colombia/.

Informe del Grupo de Memoria Histórica de la Comisión Nacional de Reparación y Reconciliación. Mujeres y guerra. Bogotá: Edición conjunta Altea, Taurus, Alfaguara, Ediciones Semana, 2011.

Lonergan, Bernard. Método en teología. Salamanca: Sígueme, 1994.

Mancera, Jaime. «De una pastoral en la ciudad a una pastoral urbana». Revista Seminario Bogotense 1 (2002). Consultada en junio 14, 2013. http://pastoralurbanabogota.blogspot. com/2009/01/revista-seminarium-bogotense-n-1-2002.html. 
Mardones, José M. Fe y política. El compromiso político de los cristianos. Santander: Sal Terrae, 1993.

Metz, Johann B. Memoria passionis. Una evocación provocadora en una sociedad pluralista. Santander: Sal Terrae, 2007.

. «Compasión. Sobre un programa universal del cristianismo en la era del pluralismo cultural y religioso». En Foro Ignacio Ellacuría Solidaridad y Cristianismo Radicalizar la democracia. Coordinado por José A. Zamora, 263-276. Estella: Verbo Divino, 2001.

Moxnes, Halvor. Poner a Jesús en su lugar una visión radical del grupo familiar y el Reino de Dios. Estella: Verbo Divino, 2005.

Niño, Francisco. «De la pastoral en la ciudad a la pastoral urbana». Cuestiones Teológicas 88, Vol. 37 (2010): 399-416.

. La Iglesia en la ciudad. El fenómeno de las grandes ciudades en A. L, como problema teológico y desafío pastoral. Roma: Tesis Gregoriana, 1996.

Parra, Alberto. Textos, contextos, pretextos. Teología fundamental. Bogotá: Pontificia Universidad Javeriana, Facultad de Teología, 2003.

Preciado Beltrán, Jair. Bogotá región: crecimiento urbano en la consolidación del territorio metropolitano. Bogotá: Universidad Distrital Francisco José de Caldas, 2005. Consultada en junio 20, 2013. http://200.69.103.48/ comunidad/dependencias/facultades/medioambiente/ Documentos/Eventos/Seminario-Internacional/PonenciasCentrales/BOGOTA\%20REGION\%20CRECIMIENTO\%20URBANO.pdf.

Prieto Rodríguez, M. A. y March Cerdá, J. C. «Paso a paso en el diseño de un estudio mediante grupos focales». Aten Primaria 6, Vol. 29 (2002): 366-373. Consultada en mayo 7, 2013. http://es.scribd.com/doc/74110812/Que-es-el-grupofocal\#download. 
Revista Semana, proyecto Víctimas. Consultada en junio 14, 2013. www.semana.com/Especiales/proyectovictimas/crimenesde-la-guerra/masacres-desplazamiento/index.html.

Sândalo, Bernardino. «Cultura urbana e evangelização». Revista Eclesiástica Brasileña 196, (1989): 877-898.

Sassen, Saskia. Contrageografías de la globalización. Género y ciudadanía en los circuitos transfronterizos. Traficantes de Sueños. Madrid: Publidisa, 2003.

Sobrino, Jon. «Con Medellín Dios pasó por América Latina, ¿̇con quién pasa ahora? Reflexión para la cuaresma 2012». Informativo Eclesalia.net 23.02.12. Consultada en abril 1, 2013. http:// eclesalia.wordpress.com/2012/02/23/con-medellin-diospaso-por-america-latina-con-quien-pasa-ahora/.

Sobrino, Jon. El principio misericordia. Bajar de la cruz a los pueblos crucificados. Santander: Sal Terrae, 1992.

Useche, Oscar. Ponencia «Territorio, nuevas formas de desarrollo. El territorio como organismo vivo». Cuarto Congreso de Pastoral Urbana. Diócesis de Engativá. 2012.

Vícaría Episcopal Territorial del Espíritu Santo. Consultada en septiembre 19, 2011. www.arquibogota.org.co/?idcategoria $=336$.

Enviado: 18 de junio de 2013 Aceptado: 21 de octubre de 2013 